\title{
Physical Education and Moral Embodiment in Primary Schools of the People's Republic of China
}

\section{Gladys Chicharro-Saito}

\section{(2) OpenEdition \\ 1 Journals}

\section{Electronic version}

URL: http://journals.openedition.org/chinaperspectives/3273

DOI: 10.4000/chinaperspectives.3273

ISSN: 1996-4617

\section{Publisher}

Centre d'étude français sur la Chine contemporaine

\section{Printed version}

Date of publication: 1 January 2008

Number of pages: 29-39

ISSN: 2070-3449

\section{Electronic reference}

Gladys Chicharro-Saito, « Physical Education and Moral Embodiment in Primary Schools of the People's Republic of China », China Perspectives [Online], 2008/1 | 2008, Online since 01 January 2011, connection on 28 October 2019. URL : http://journals.openedition.org/chinaperspectives/3273 ; DOI : 10.4000/chinaperspectives.3273 


\title{
Physical Education and
}

\section{Embodiment of Morality}

\section{in Primary Schools of the}

\section{People's Republic of China}

\author{
GLADYS CHICHARRO-SAITO
}

This article examines the Chinese practice of body molding of children through detailed analysis of "physical education" and "physical exercise" as taught in Chinese primary schools. It shows that while some practices from the Maoist period may remain in use today, they have evolved or their meaning has been changed for adaptation to new aims and to the circumstances of China's only-child generation. Children must now embody a new set of moral values advocated by government.

$\square$ very morning at $07: 50$, pupils gather in the playgrounds of the great majority of schools in the People's Republic of China. Standing in rows, class by class, they perform a ten-minute exercise choreographed in a rather militaristic style. Their movements are set to music, an eight-beat rhythm, blaring out from loudspeakers. These "radio physical exercises" (guangbo ticao) have been carried out in the open air in all schools and many work units since 1951. As in the case of "exercises to protect the health of the eyes" (yanbao jiancao) or physical education classes, the original aim was to "strengthen the physical qualities $s$ of the people" (zengqiang renmin tizhi), in line with Maoist terminology. ${ }^{(1)}$ Today the context is quite different. In the schools, it is said that physical exercises help to "stimulate healthy growth and harmonious development in young people and children" (cujin qingshaonian jiankang chengzhang, hexie fazhan). For pupils in the current generation of onechild families, physical performance is no longer the priority, but has been replaced by "health" and "harmony" - term dear to President $\mathrm{Hu}$ Jintao.

In China as everywhere else, school is a place where individual bodies are moulded by state and society. Mostly, the process is designed to standardise children's behaviour and "domesticate" their natures, which are deemed still a little wild. Some sociologists or philosophers even use expressions such as "to tame" (2) and "taming" ${ }^{(3)}$ for this process. This body moulding takes place continuously in schools, but its objectives are most obvious in what is called physical education, gym, or sport. In September 2001 I began carrying out field research in a primary school in a new town of Hebei Province. I spent nearly two years observing how the school was run and how the children were educated. Starting with a detailed description of the teaching classified as "physical exercise" (ticao) and "physical education" (tiyu), I will explain the role assigned to body training in today's Chinese schools.

\section{"Develop physical education and sport: improve the physical capacities of the people}

The terms for physical education (tiyu) and physical exercise (ticao) both appeared in China at the end of the nineteenth century as translations of Western concepts. The first

1. Mao's famous slogan "Develop physical education and sport: improve the physical capacities of the people" (fazhan tiyu yundong, cengqiang renmin tizhi) was launched on 10 June 1952. The slogan is still displayed in most of China's schools, stadiums, and gymnasiums.

2. Emile Durkheim, Éducation et sociologie, Paris, PUF, [1922] 1985, cf. pp. 5 and 22 in particular.

3. Michel Foucault, Surveiller et punir, Paris, Gallimard, [1975] 2004, in particular pp. 159-199. Foucault speaks of an actual "disciplinary control" over the body that has been widespread in schools and armies since the eighteenth century in Europe, modeled on prison regimes and aimed towards greater efficiency and swiftness of action. 

December, the entire population was invited, with a fanfare of trumpets, to join in morning sessions of choreographed training. New series of exercises were launched in 1954, 1957, 1963, 1971, 1981, 1990, and 1997. ${ }^{(8)}$ At the same time, the Ministry of Education devised and then introduced exercises specifically aimed at children as an integral part of school timetables. In the early stages, the exercise sessions followed the daily flag-raising ceremonies, which left no doubt as to their military and political significance. Now the flag is raised only weekly, ${ }^{(9)}$ and the "radio physical exercises" are carried out independently. In the school where I carried out my research, the flag flies from a mast in the entrance yard, whereas the "radio physical exercises" are held on the sports ground behind the classroom blocks, sometimes not at the beginning of the school day but a few hours later. With this complete removal from their original context, "radio physical exercises" seem to have gradually left military training behind while acquiring a new meaning; health seems to have taken over from nationalism

At the beginning of the school year, a teacher, sometimes standing on a raised platform, demonstrates the movements to be performed while bellowing all sorts of advice into a megaphone. A few weeks later, the teacher is replaced by a "model" pupil (bangyang) who leads the whole school, but each class is also led by its own "model" pupil standing slightly ahead of the group and responsible for leading them through the exercises. Each series of programmes is set to its own music. During my field studies I became familiar with two choreographed sequences entitled "The Eaglet Takes Flight" (chuying qifei) and "The Rising Sun" (chusheng de taiyang). ${ }^{(1)}$ The first begins and ends with movements imitating a bird's wings as it flies off from the nest, hence its name. The exercises include movements to stretch the arms, legs, and chest, and little running jumps. "The Rising Sun" is more like a military march. It begins with head turns to the right and left while stretching the arms in time to the music. Next come quarter turns and hand claps, still to the same rhythm, followed by knee bends accompanied by arm swinging and leg stretching. Twisting and flexing of the upper body introduces a sequence of small jumps with high kicks in the purest French cancan style. Other movements seem to be inspired by Russian folk dances, or perhaps by tap-dancing. These exercises always suggested to me a clever combination of military drill and an improvised form of aerobics, bringing together a few simple movements borrowed from the most diverse dance forms.

Creating a series of routines based on elements drawn from various unnamed sources, simplified and set out as a model for the whole population: such techniques were constantly employed during the Maoist period. ${ }^{(1)}$ Many schools organised and still organise annual "competitions of radio physical exercises" (guangbo ticao bisai) that are supposed to encourage the practice. On such occasions, each class "takes on" the others, performing the drill before a panel of teachers. The judges evaluate the movements from both the sporting and artistic points of view, also taking into consideration the overall impression created, and how the uniform is worn. In fact, more and more pupils are refusing to wear uniforms, and most teachers and school heads express sympathy for this attitude: "Look at the attractive coloured clothes that are being produced today! It's natural that children should prefer them!" In general, uniforms are compulsory only on Monday mornings for flag-raising; sometimes pupils can satisfy the requirement by simply wearing a red scarf. However, the full uniform must be worn for class outings as well as well as for ceremonies and similar competitions. "Radio physical exercises" are among the few remaining instances where collective unity and the rejection of individualisation is still glorified. Only "model" pupils can gain distinction by performing the sequence to perfection and forcing themselves to wear the uniform when everyone else refuses.

The children of today, who were born long after Mao's death, and who as only children have learned to express their individuality, often consider this activity a sort of revolutionary anachronism. "It's as though we were still living during the Cultural Revolution!" the older ones sometimes say. They do not take it at all seriously, and comic clips from these morning sessions, filmed using mobile phones, are regularly posted on video-sharing websites, typically showing one or two pupils playing the fool behind the backs of absent-minded teachers. Other school children prefer to invent new exercise sequences adjusted to contemporary

8. Parallels between these dates and political events are striking. 1954 was the year when the first constitution was published; 1957 saw the "hundred flowers" anti-rightist crackdown; 1963 was when Mao launched the People's Education Movement that prefigured the Cultural Revolution; in 1971 Lin Biao died; in 1990 the Communist Party was shaken up following the demonstrations of 1989; and in 1997 Deng Xiaoping died.

9. Flag-raising takes place every Monday morning, more ceremonially in some schools, less so in others. Sometimes three or four pupils are assigned to raise the flag, while the others play or make their way to their classrooms, paying no attention to the ceremony, a scenario that would have been unthinkable a few years ago.

10. The video models (guanmo biaoyan) for these courses broadcast by the Ministry of Education are viewable on various Internet websites, in particular www.sina.com, v.youku.com, and tudou.com. Cf. for example "The Eaglet Takes Flight," http:// www.56.com/u72/v MjU4MjU0MjE.htmlor, http://v.youku.com/v show/id co00X0D YyMDgw.html, and "Sunshine at Dawn,"http://v.youku.com/v_show/id_ce00XODY XNzQ0.html.

11. The model revolutionary operas of the Cultural Revolution or the official model sequences of taiqi quan accompanied by music are examples. 


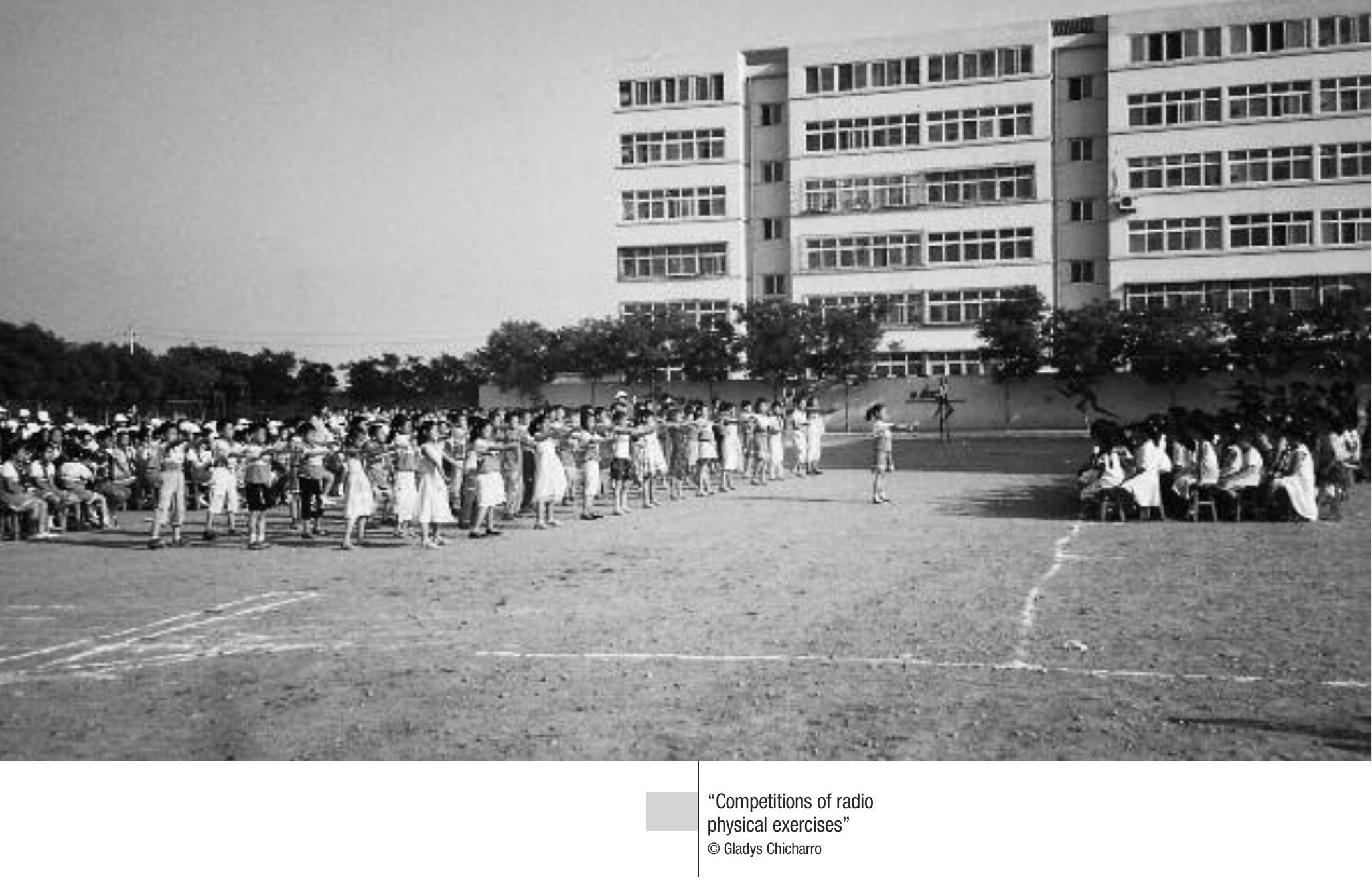

taste. Some, like the "mobile phone radio physical exercise," are posted on the Internet.

Last June, the Ministry of Education launched its "collective dances" (jitiwu), undoubtedly in response to criticisms of the "radio physical exercises" as "outdated" (guoshi). A ministry spokesman explained that two years had been spent on the "scientific" development of the new dances so that they would be perfectly adapted to the physical capacities and interests of children of different ages. ${ }^{(12)}$ The new aim is to "promote the moral, intellectual, physical, and aesthetic development of the pupils" (cujin xuesheng de, zhi, ti, mei quanmian fazhan). To Mao Zedong's trilogy (borrowed from Herbert Spencer) - moral, physical, and intellectual education - has been added the new element of aesthetics. So far, three dances have been devised for the primary level: "Good Friends" (hao pengyou), "The Sunny School" (yangguang xiaoyuan), and "The White Boat" (xiao bai chuan); and four for secondary schools: "The Melody of Youth" (qingchun xuanlü), "The Yangge of the School" (13) (xiaoyuan yangge), "The Presence of Youth" (qingchun fengcai), and "The School Waltz" (xiaoyuan huaerzi). ${ }^{(14)}$ The mixing of Chinese and Western references, as between yangge and waltz, is a regular feature in the latest school syllabuses, and judging by the model videos posted on the Internet, these new exercise routines suggest a fusion between Western ballroom dancing, the folk dances of East and West, and the rock and pop dance styles of the 1980s. They are accompanied by melodies borrowed from folk songs, and sometimes approach techno-pop for the older pupils. The militaristic marching influence reflected in the "radio physical exercises" has completely disappeared.

In September 2007, the "collective dances" were introduced on a trial basis in a few schools: it was impossible to train all PE teachers in the dances over the summer. The dances do not seem to have been greeted with the enthusiasm the Education Ministry had hoped for; urban children considered them as ridiculously outdated as the "radio physical exercises," and were embarrassed by movements requiring children to hold hands in pairs. This feature has also aroused controversy among some teachers and parents, who worry that it might lead young people into premature love-affairs (zaolian), and distract them from the only legitimate purpose: academic and professional success. Taking such sharp

12. Xinhua News Agency, 4 June 2007.

13. The yangge is a popular dance, originally an evocation of working in the fields. Interest in the dance revived strongly during the 1980s. In the urban context it is regularly danced at nightfall by local residents gathered in associations or committees. Cf Florence Graezer, "Le yangge en Chine contemporaine. Pratique populaire quotidienne et vie associative de quartier," Perspectives chinoises, $n^{\circ} 53,1999$, p. 31-43.

14. The model videos for these "collective dances" may be viewed on the website www.tudou.com 
exercises are still recommended, and some teachers continue to attach great importance to them. Some teachers of the Chinese language, in particular, invariably start their classes with this exercise: they say it helps children to relax their eyes in readiness for the effort demanded by reading. Moreover, unlike the "radio physical exercises," this exercise is not unpopular with the pupils, as it gives them a few minutes' rest during stress-filled days. Even so, statistics published by the World Health Organisation in 2007 provoked a brief controversy by challenging the value of this form of exercise, given the fact that China has one of the world's highest myopia rates. Since the "exercise to protect the health of the eyes" is a specifically Chinese activity, some suggested it might actually cause this national weakness. Nevertheless, defenders of the "exercise to protect the health of the eyes" quickly rallied to its defence, and came up with a new historical context that no longer cites the Maoist desire to improve the physical capacities of the population. The media now assert that it was Professor Liu's deep knowledge of ancient Chinese medicine that inspired him to create this sequence of "massages" (anmo) - no longer referred to as "exercises." Doctors of leading national institutions were enjoined to remind citizens that the 12 meridians are intimately connected to the eyes, and that the massage movements bring acknowledged acupuncture points into play. In this way, while the prescribed movements have remained unchanged since 1972, the references associated with them have radically changed.

The "physical exercises" inherited from the Maoist period must now take on entirely different meaning if they are to be practiced today, or else they will simply disappear. The notion of improving the physical capacities of the people, inseparable from old propaganda images of peasants with tall, strong, and vigorous bodies, has faded away, to be replaced by a reversion to a concept of health care closer to the Chinese notion of "nourishing the vital principle" (yangsheng). In the school where I did my research, Mao's famous slogan "Develop physical education and sport: improve the physical capacities of the people" was written on chalk in huge white characters on a blackboard in the room where the equipment used in PE classes is stored. Between the characters for "sport" and "physical qualities" a child had drawn the head of a boy wearing a cap, with the character for "explode" (pao) scrawled where his nose should be. This drawing remained on show for weeks, unnoticed by any of the adults. Without over-estimating the symbolic value of this graffiti, we can see a real indifference, even mockery, toward the obligations of earlier times.

\section{"School children should practise physical education and movement for an hour a day"}

In addition to "physical exercises," there is a school subject called "physical education and movement/activity" (tiyu huodong). ${ }^{(17)}$ The term "movement/activity" is made up of the character huo, meaning "life," and dong, "to move, to act." Literally, it means "movement of life," but the translations suggested in dictionaries are the verbs "to move, to act, to take exercise," or else the corresponding nouns "activity, physical exercise, movement." Huodong is a very common term with extremely diverse usage: a demonstration, a political movement, a celebration, a religious ceremony, or a game may be called a huodong. In schools, it is an expression that is intrinsic to contemporary pedagogical discourse, and refers not only to $\mathrm{PE}$ lessons, but to any exercise requiring movement of the entire body, or any "activity" that is part of social life. A trip to a museum, a visit to a factory, picking up autumn leaves: all such activities might be designated in this way.

As a general rule, children in their first two years of primary schooling have four 40-minute sessions of "physical education and movement" every week. Thereafter, the number of sessions falls to three. ${ }^{(18)}$ In 2005, the Education Ministry launched a new slogan: "School children should have physical education and activities for an hour a day" (Luoshi zhongxiaoxuesheng meitian yi xiaoshi tiyuhuodong), but many schools have not yet implemented this instruction.

\section{A model lesson: "Plant trees in Mongolia"}

The school where I carried out my field research is relatively new (built in 1997) and is situated in a new and prosperous town. As a result, its infrastructure is far superior to that provided to most of China's municipal schools. Physical education teachers have access to a vast stretch of

17. This expression, translated word for word, would be "movements/activity of physical education". However, for the people I spoke to, these were two juxtaposed words designating potentially different but linked practices. The names of other school disciplines are formed according to the same principle from two associated words.

18. Primary education is dependent on local government, so there may be variations between provinces or between districts. 


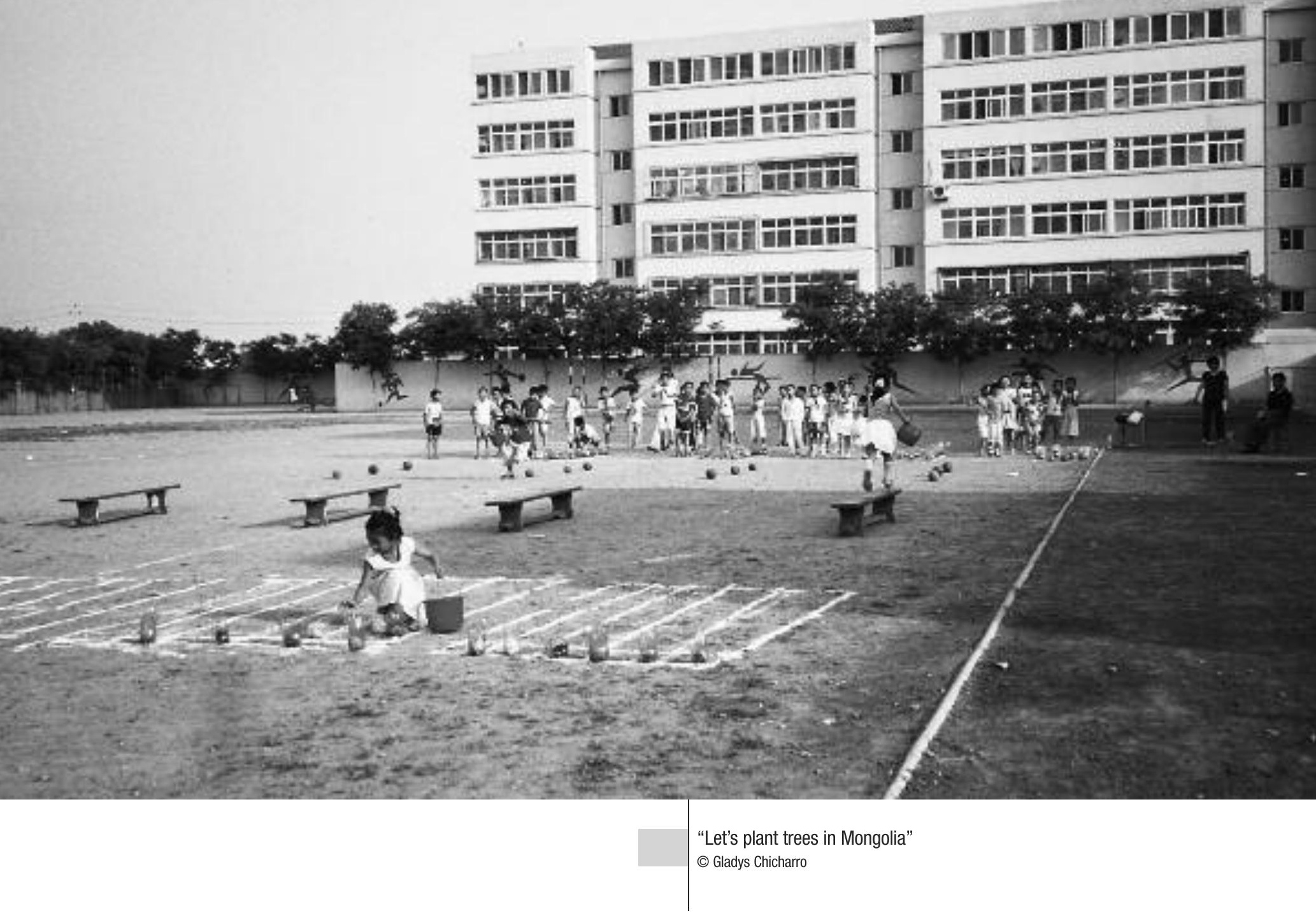

dry earth equipped with rather old goal-posts, a small tarred basketball area with four baskets, and an inside hall, which is rather small given the number of pupils per class, ${ }^{(19)}$ but equipped with a large mirror and a piano. There is also the storeroom mentioned earlier, where balls, table-tennis bats, mats, hoops, sticks, and skipping-ropes are stored. These various objects were regularly used during the PE classes I attended.

At this point I will describe a significant model lesson at this school, followed by an analysis of its content. The teacher I observed, who also served as head of physical education, made lengthy preparations for the lesson in order to compete with several other PE teachers in the district. I was able to observe a trial presentation of this class in the presence of a former deputy head of the school (recently retired; but he had been a sports teacher early on in his career) and the new deputy head in charge of the pedagogy. Both offered the teacher a wide range of advice on improving her presentation. Lastly, I observed her presentation on the day of the teacher's competition, where she won first prize. The teacher conducted her lesson for the first time with pupils in their first year at primary school, aged between six-and-a-half and seven-and-a-half, ${ }^{(20)}$ and for the second time with second year children.
The teacher gathers the children around her in the open-air sports ground. She asks them to sit down on the ground, and they do so. "Good morning, children!" the teacher greets them, and they reply in chorus, "Good morning, Miss!"

She explains that today she is taking them on a journey, and she invites them to close their eyes. They do so. Then she plays a cassette of traditional Mongolian music. When the music stops, she tells them they are going to the great plains of Mongolia. "Have you been there before?" she asks. "No!" the children answer in chorus. The teacher talks to them about the blue sky, the birds, and the green grass. "Isn't it beautiful?" The pupils answer in chorus, "It's beautiful!" Next she asks them to stand, and they line up in rows. Then she shows them a series of movements, which they imitate: the eagles flying and the rabbits jumping, the animals of the great plains of Mongolia. Then she explains that the traditional sports there are archery and wrestling. She demonstrates; they imitate

19. In this school there are between 40 and 70 children per class, which is quite usual for an urban municipal school.

20. The legal age in the People's Republic for starting primary school is six-and-a-half. 
her. Next she asks them if they would like to ride a horse. "Oh, yes!" Following her instructions, the children make a circle and trot around like little horses, swinging their arms like horsemen waving their lassos. Back in their rows, they watch the teacher's hand movements, which imitate people climbing a hill and climbing down again. They follow suit. The teacher puts the music on again and shows them a "Mongolian dance" based on these various movements. The children follow her example.

After this opening sequence, the teacher gathers the pupils around her again to talk to them about deforestation. "To protect the great plains of Mongolia," they have to replant the trees: that's what they are going to do in this next exercise. She divides the children up into four teams, separating the girls from the boys. Each team is allocated the same number of "tree plants," represented by green plastic bottle bottoms trimmed to look like plants and a red bucket (a reed basket on the day of the competition) to carry them in. Then the teacher explains the rules of the relay race. Each child must take a tree in the bucket/basket and run around a little circuit weaving in and out around balls (pegs on the day of the exam) - the forest; walking along a bench - a bridge; and planting the tree in a bed at the other end of the sports ground before running back with the empty bucket or basket so that the next member of the relay team can tackle the same course. The winning team is the first to plant all its trees.

The children shout support for the members of their teams with the appropriate phrase: literally in Chinese "Add more fuel!" (jiayou). The teacher exhorts the losers to applaud the winners, though some, apparently displeased with the result, do not join in. She hands out yellow caps to the winners, then tells all the pupils to "remount their horses" and go to see what they have planted. The children are horses again: they resume the trotting movements they learned at the start of the lesson and form a circle around the trees. The music starts again, and the children sing a round. The teacher goes on to explain that we must love nature and protect the environment. She brings the lesson to a close with the sentence, "Next time I will take you on a journey to another place."

She asks the children to put the objects they used (bottle bottoms, benches....) back in the storeroom, which they do. The winners return their yellow caps to the teacher.

\section{From the rabbit dance to basketball}

This lesson is particularly significant, bringing together almost all the defining characteristics of a primary school PE class. The first element, also present in the "radio physical exercises," is the importance attached to music and dance. The tape recorder is constantly used by PE teachers, which may be explained at several levels. Firstly, physical education is classed in the same category of subject as music: they both involve a strong participation of the body and movement: they are huodong. Indeed, it happens quite often that a single teacher teaches both subjects, or that the teacher of one may be asked to stand in for the other in case of absence. ${ }^{(21)}$ In addition, singing and dancing were traditionally considered among the best ways of educating the youngest children. Jacques Gernet cites several neoConfucian educationalists who recommended singing and dancing for instilling rituals into the unfinished and malleable bodies of children, while allowing them to express their need to shout and jump about. ${ }^{(22)}$ Today's teachers do not consult their illustrious "predecessors," but their discourse is noticeably similar: "Children like to sing and dance, and that helps them acquire good habits." We will be looking more closely at these habits.

Another recurrent feature of PE classes is imitating the movements of animals, usually birds, horses, or rabbits. The teachers explain this by saying that children love animals and appreciate activities that refer to them, but one cannot avoid seeing the influence of other ancient physical practices, such as the martial arts, which refer just as extensively to animals. In most PE classes, all children learn the same movements at the same time, as in choreographed dances. When they are divided into teams, the aim is generally to organise a relay race that puts all the children through the same exercise course in turn. At the primary level, I have never seen

21. In urban schools, primary and onwards, children have several teachers, usually seven one to teach the Chinese "language" (yuwen) and "moral quality" (pinde), one for maths (shuxue), one for nature study (ziran), one for art (meishu), one for IT (weiji); lastly there are two teachers, or sometimes just one, for physical education (tiyuhuodong) and music (yinyue)

22. Jacques Gernet "L'éducation" in L'intelligence de la Chine, Paris, Gallimard, 1994, pp. 98-137 et "L'éducation des premières années (du xie au xviie siècles)" in Catherine Despeux and Christine Nguyen Tri, Éducation et instruction en Chine, Paris Louvain, Peeters 2003, pp. 7-60. On the connections between rituals, music, and dance, cf. also Anne Cheng, Histoire de la pensée chinoise, Paris, Seuil, 1997, p. 80 “... les rites dont l'aspect esthétique de formalisme harmonieux les associe tout naturellement à la musique et à la danse." 
any match organised with a different role assigned to each pupil. Even a class introducing children to basketball, the modern sport par excellence, for which the teachers were able to call up the national idol, Yao Ming, the star of the National Basketball Association, did not end with a match. Instead, it started with rabbits dancing to music in order to learn to jump, and it ended with a relay race in which each member of the four teams ran a short distance before trying to shoot a basket and then bringing the ball back for the next child. In primary schools, physical education is not yet sport (yundong) - that comes later, its main purpose being quite different. The word for sport means literally "movement" or "moving," and is used in many other contexts, in particular for political campaigns.

\section{Physical education, moral education}

The physical education lesson described above is obviously designed to develop certain motor capacities. Children perform various movements imitating animals or activities that, in Chinese eyes, characterise Mongolia or the Mongolians (the eagle, the rabbit, archery, galloping on horses, swinging a lasso, and wrestling). They participate in relay races, training themselves to run swiftly while avoiding obstacles. But in reality, the aim is also to inculcate in the children a value that in recent years has assumed ever greater importance in China: the protection of nature and the environment, and the importance of reforestation. This lesson also informs children about the geography of Mongolia and its inhabitants' way of life, while relating it to China, so it is possible to detect nationalist content. All in all, this lesson transmits what the Chinese call "moral quality" (pinde). This term crops up constantly in the field of education. It has even become the title for a specific subject, which up until $2001{ }^{(23)}$ was called "thought/ideology and moral quality" (sixiang pinde) and was designed for children in their first three years of primary school. It was followed from the third year onwards by classes in "society" (shehui). These two subjects, which in reality make up just one subject, have since been renamed: first and second year children study "life and moral quality" (shenghuo yu pinde), and from the third year upwards children study "moral quality and society" (pinde yu shehui). The subject "thought/ideology" (sixiang) has disappeared from the new syllabuses, which is very revealing. Its title referred implicitly to "ideological education" (sixiang jiaoyu), which all Chinese people had to undergo during the harshest periods of Communism in order to learn to think properly - that is to say, along the lines pre- scribed by Mao. By deciding to abandon this word, the government seems to have put aside this ideological, political, and theoretical aspect of Marxist moral teaching in favour of something else: "moral quality" (pinde), which appears in the titles of both the new subjects. Pin has the sense of "quality," and refers to a class or a stratum on a scale. De immediately recalls the Confucian terms "virtue" and "moral strength." The rehabilitation of a modernised neoConfucianist form of virtue in schools has become increasingly apparent for some years. It often helps to mask the ideological ambiguity between the Marxist-Maoist references and liberalism in which children are educated.

The subject "moral quality" covers a wide range of teaching, from standards of behaviour in public and the rules of hygiene, to what in France would be classified under the headings of civics, history, and geography. The purpose behind "moral quality" is to give children a necessary understanding of the new society in which they are living so they can navigate within it easily but also correctly - that is to say, while keeping patriotic feelings. ${ }^{(24)}$

This digression into the lessons on "moral quality" is instructive, because the PE classes described above are charged with a content identical to that found in the textbooks on "life and moral quality" and "moral quality and society" published since 2001 by the People's Education Press (renmin jiaoyu chubanshe), among others. Indeed, the PE lessons and the morality lessons ideally convey the same values.

23. In June 2001, the Education Ministry launched a teaching reform with the publication of a "circular concerning reforms to the basic education syllabus (experimentation)," Jichu jiaoyu kecheng gaige gangyao (shixing). Local administrations started progressively applying these new directives. The education authority in the town where I was carrying out my research opted to implement the new syllabuses starting in the school year 2003-2004, beginning with the youngest classes. The reforms were to be extended as that age group progressed through the school system, while those children who had started school before 2003 continued with the old syllabuses. Only in 2009, by which time those first year children of 2003 will reach their sixth year, will all the classes of all the schools be operating under the new directives.

24. For a more extensive description of how this subject is taught and of its aims, cf. Gladys Chicharro, Le fardeau des petits empereurs. Former et faconner une génération d'enfants uniques dans un contexte de modernité en Chine, Doctoral thesis, Université Paris X Nanterre, 2006, pp. 160-180. "Moral quality" is not supported by six-monthly exams, and given the time allowed for it - 40 minutes a week - seems of little importance, whereas in reality it is fundamental. It is the subject mentioned first on the "children's notebooks," xiaoxuesheng xueji shouce, even ahead of Chinese. What is more, in the district where I work, in addition to their notebooks, all the children have a "booklet for evaluating the overall quality of schoolchildren," xiao xuesheng suzhi zonghe pingjia shouce, in which the first heading is always "thought/ideology and moral quality." It is subdivided into seven points, sometimes expressed in couplets or rhyming sentences (the first, second, and seventh points are to be filled in only by the teacher, and the others by parents as well): 1 . When the flag is raised one must salute. Love the school, love the class. 2. Respect the school rules. Tell the truth, do not lie. 3. Respect teachers and parents; be united with one's fellow pupils. 4 . Do not fight; do not insult other people. 5 . Respect the rules of public transport; pay attention to road safety. 6 . Love and protect nature, both animal and vegetable; be considerate and do not throw litter; 7 . Results of classes of "thought and moral quality." 
Exercising the body has an explicit role in moral education. Of course, this is also the case, if less obviously, with the "radio physical exercises." Yet, in one of these radio physical exercises aimed at nursery school pupils, the moral purpose is very clear: while the children imitate the movements of animals, they sing edifying verses. This exercise is called, "The world is really beautiful" (shijie zhen meihao): ${ }^{(25)}$

Préparation/ Cock-a-doodle-doo shouts the cock, the world is wonderful, the children are nicely in line, let's all do our exercises, keep your distances, everyone is ready.

1/ The little sea gull is very brave, she flies high, flies far, let's learn from the little sea gull, we mustn't be afraid of difficulties.

2/ Miaow Miaow the pretty cat, turns its head to lick itself; being clean is a good habit, let's be good and healthy.

3/ Penguin brothers all in a row, while they walk they sway from side to side, they all help each other; intelligent and clever, everyone loves them.

4/ The little monkey is mischievous; look right look left, keep to the rules, don't do anything silly.

5/ Uncle elephant walks gently, stretches his trunk and nods his head, says Good Morning to the elders; everyone praises his good manners.

6/ Croak croak the little frog cannot find its mummy, let's help it; found at last, ha ha ha we all laugh.

7/ The yellow nightingale sings loudly, the children are happy; every day we do the exercises, it's very good, our world is really beautiful.

(預備) 大公雞, 喔喔叫, 外面的世界多美妙, 小朋友們排好隊, 大家快快來做操, 間隔距離要保持, 大家都要準備好。

(第一節) 小海鷗真勇敢, 飛得高來飛得遠, 我們學習小海鷗, 不怕辛苦不怕難。

(第二節) 小花貓, 喵喵叫, 搖搖腦袋称㖔毛, 養成衛生好習慣, 做個健康的乘寶寶。

(第三節) 企鵝弟弟站一排, 走起路來搖又擺, 互幫互助最團結, 聰明伶俐人人愛。

(第四節) 小猴子真頑皮, 望望東來望望西, 遵守規則不胡鬧, 快快樂樂做遊戲。

(第五節) 大象伯伯慢慢走, 伸伸鼻子仰仰頭, 見到老人問聲好, 大家誇我有禮貌。

(第六節) 小青蛙呱呱叫, 媽媽媽媽不見了, 我們一起幫助它, 找到媽媽哈哈笑。

(第七節) 小黄第高聲叫, 小朋友們齊歡笑, 天天鈠煉身體棒, 我們的世界真美好。
The radio physical exercises for older children are less explicit, but they play the same role. The theme of the eaglet taking flight, for example, refers to a lesson in the "moral quality and life" textbook. The lesson, called "Learn to be a good falcon," tells the story of a mother falcon teaching her chicks to fly. One is brave and flies unhesitatingly from the nest, even in stormy weather, whereas the other, less bold, holds back from taking flight. This is a classical metaphor for inducing only children to be independent, because that is the quality they are constantly reproached for lacking. A young PE and music teacher at the school explained it to me: "The advantage with only children is that their families take good care of them; the disadvantage is that their capacity for independence is not great."

One of the functions attributed to PE and exercise, therefore, is to instil in the body the moral behaviour taught during lessons of "moral quality." These two subjects, moreover, have followed a similar evolutionary process over the years: the Marxist ideological aspect (that is to say, in the case of PE, the military and disciplinary aspect) tends to disappear and is replaced by the inculcation of values, newly appreciated, in the body. Just as was recommended by neo-Confusion teachers in ancient times, the children of today learn their morality "in action." (26) That explains the very important role assigned in many cases to PE teachers. The head teacher of each class (ban zhuren) are often, as in the West, teachers of Chinese or Maths. Yet, in the school where I worked, there is also the post of senior teacher responsible for all the classes in the first and second years: the teacher of Music and Physical Education. He or she is best placed to educate the body and also the morals of the youngest children.

\section{Conclusion: Only children and the capacity for movement}

The PE and exercises practised in primary schools today in China are both inherited from the recent Maoist past, while having undergone profound mutations to adapt to modernisation, economic development, and the unique feature of recent generations of urban children: the preponderance of single-child families. Some disciplinary, military, and collectivist aspects of training the body do persist, but they tend to

25. Cf. http://you.video.sina.com.cn/pg/topicdetail/topicPlay.php?tid=518042\&uid=12900 29655\#3168545 for a video of this sequence.

26. In a way, we find here what Jacques Gernet calls the "morality of behaviour" (cf. "L'éducation", art. cit.), and Marcel Granet calls "the morality of attitude" (La pensée chinoise, Paris, Albin Michel [1934] 1999, p. 328.) and James Watson "orthopraxy." 
disappear under contemporary pressures and among children who have increasing difficulty accepting them.

For the state, the obsession is no longer so much with breeding people physically capable of rivalling those in the West: the improvement in food resources has taken care of that. Of course, China still wants to make its citizens tall and strong "like Americans," say some teachers, but they also want to avoid the West's health problems through their own traditional medical genius.

Moreover, teachers consciously and very openly emphasise the moral side of physical education. ${ }^{(27)}$ Within the bodies of children disorientated by the ideological ambiguity surrounding them, teachers seek to implant a set of undisputed values, such as protection of the environment and respect for the elderly. Physical education and exercise are perceived as a means of curing all the ills commonly attributed to only children. Thus, exercises at school stress collectivity to counter individualism. In addition, one often hears the assertion that China's "little emperors" lack the "capacity for movement/action" (huodong nengli). Strictly speaking, this describes only urban children, who no longer play outside and who take little exercise, while being plied with "strengthening" foods, even medicines, that are good for growth or memory. At the same time, as these children have become keen on "Western foods" (biscuits of all kinds, types of buttered brioches, sugary drinks, and hamburgers), some have grown fat. According to their elders, children are becoming clumsier in using their bodies; walking soon tires them, they can no longer climb hills, and they twist their ankles walking on rough paths. They have lost their ease of movement, or more figuratively, they have lost their autonomy of action. Indeed, with up to six people looking after them (two parents and four grandparents), they lack initiative. In the long term this could have very bad consequences for a country that, for nationalistic purpose, now encourages creative entrepreneurs and innovative scientists. In sum, PE classes today have the duty both to transmit autonomy and independence and to fight against individualism.

\section{- Translated by Philip Liddell}

27. A far less common tendency in the West.

\begin{tabular}{|c|c|c|c|}
\hline $\begin{array}{l}\text { Glossary } \\
\text { Bixia yuanjun } \\
\text { anmo } \\
\text { bangyang } \\
\text { ban zhuren } \\
\text { chusheng de taiyang } \\
\text { chuying qifei } \\
\text { cujin qingshaonian jiankang } \\
\text { chengzhang, hexie fazhan } \\
\text { cujin xuesheng de, zhi, ti, } \\
\text { mei quanmian fazhan } \\
\text { dajia lai zuo guangbo ticao } \\
\text { dongya bingfu } \\
\text { fazhan tiyu yundong, } \\
\text { cengqiang renmin tizhi } \\
\text { guangbo ticao } \\
\text { guangbo ticao bisai } \\
\text { guanmo biaoyan } \\
\text { guoshi } \\
\text { hao pengyou } \\
\text { huodong nengli } \\
\text { jiayou } \\
\text { Jichu jiaoyu kecheng gaige } \\
\text { gangyao (shixing) } \\
\text { jitiwu } \\
\text { Jitiwu bu hui qudai guangbo } \\
\text { ticao, ye bu hui wei caolian } \\
\text { tigong tiaojian } \\
\text { Liu Shiming } \\
\text { Luoshi zhongxiaoxuesheng } \\
\text { meitian yi xiaoshi tiyuhuodong } \\
\text { meishu } \\
\text { pao }\end{array}$ & $\begin{array}{l}\text { 碧霞元君 } \\
\text { 按摩 } \\
\text { 榜樣 } \\
\text { 班主任 } \\
\text { 初升的太陽 } \\
\text { 觹鷹起飛 } \\
\text { 促倠青少年健康 } \\
\text { 成長、和借發展 } \\
\text { 促進學生德、 } \\
\text { 智、體、美全面發展 } \\
\text { 大家來做廣播體操 } \\
\text { 東亞病夫 } \\
\text { 發展體育雲動, } \\
\text { 增強人民體質 } \\
\text { 廣播體操 } \\
\text { 廣播體操比賽 } \\
\text { 觀摩表演 } \\
\text { 過時 } \\
\text { 好朋友 } \\
\text { 活動能力 } \\
\text { 加油 } \\
\text { 基礎教育課程 } \\
\text { 改革網要 (試行) } \\
\text { 集體舞 } \\
\text { 集體操不會取代廣播操 } \\
\text { 《也不會為早戀 } \\
\text { 提供條件》 } \\
\text { 劉世銘 } \\
\text { 落實中小學生每天一 } \\
\text { 小時體育活動 } \\
\text { 美術 } \\
\text { 炮 }\end{array}$ & $\begin{array}{l}\text { pinde } \\
\text { pinde yu shehui } \\
\text { qingchun xuanlü } \\
\text { qingchun fengcai } \\
\text { renmin jiaoyu chubanshe } \\
\text { shehui } \\
\text { shijie zhen meihao } \\
\text { shuxue } \\
\text { sixiang } \\
\text { sixiang jiaoyu } \\
\text { sixiang pinde } \\
\text { shenghuo yu pinde } \\
\text { ticao } \\
\text { tiyu } \\
\text { tiyu huodong } \\
\text { Tiyu zhi yanjiu } \\
\text { weiji } \\
\text { weile geming baohu shili } \\
\text { xiao bai chuan } \\
\text { xiao xuesheng suzhi zonghe } \\
\text { pingjia shouce } \\
\text { xiaoxuesheng xueji shouce } \\
\text { xiaoyuan huaerzi } \\
\text { xiaoyuan yangge } \\
\text { yanbao jiancao } \\
\text { yangguang xiaoyuan } \\
\text { yangsheng } \\
\text { yinyue } \\
\text { yundong } \\
\text { yuwen } \\
\text { zaolian } \\
\text { zengqiang renmin tizhi }\end{array}$ & $\begin{array}{l}\text { 品德 } \\
\text { 品德與社會 } \\
\text { 青春旋律 } \\
\text { 青春風采 } \\
\text { 人民教育出版社 } \\
\text { 社會 } \\
\text { 世界真美好 } \\
\text { 數學 } \\
\text { 思想 } \\
\text { 思想教育 } \\
\text { 思想品德 } \\
\text { 生活與品德 } \\
\text { 體操 } \\
\text { 體育 } \\
\text { 體育活動 } \\
\text { 體育之研究 } \\
\text { 微機 } \\
\text { 為了革命保護視力 } \\
\text { 小白船 } \\
\text { 小學生素質綜合 } \\
\text { 評價手册 } \\
\text { 小學生學籍手册 } \\
\text { 校園華爾兹 } \\
\text { 校園秧歌 } \\
\text { 眼保健操 } \\
\text { 陽光校園 } \\
\text { 養生 } \\
\text { 音樂 } \\
\text { 運動 } \\
\text { 語文 } \\
\text { 早戀 } \\
\text { 增強人民體質 }\end{array}$ \\
\hline
\end{tabular}

